\title{
Preliminary data of the Cannero Riviera mineralized system (Southern Alpine Domain, Western Alps, Italy)
}

\author{
Matteo Oberto (1) \& Alessandro Petroccia (1)
}

(1) Department of Earth Sciences, University of Turin, Via Valperga Caluso 35, Turin, Italy.

Corresponding author e-mail: matteo.oberto183@gmail.com

Document type: Article

Manuscript received 19 June 2020; accepted 23 November 2020; published online 23 February 2021; editorial responsibility and handling by R. Cirrincione.

\section{ABSTRACT}

Geometry and composition of veins associated with ore deposits, combined with mineralogical and textural constraints, are indispensable to understand the evolution of mineralized systems. The never mined Cannero Riviera mineralized system (VCO province, Western Alps, Italy), has been detected in 2015 by Alpine Gold Lodes Snc and after investigated during the Oberto's Master Thesis in 2019. Preliminary field data, integrated microstructural and petrographic investigation, combined with SEM-EDS and ICP and XRF techniques are fundamental tools to unravel mineralized systems. Our results highlighted the strong relationship between orebody and the Rio Cannero Fault activity, well displayed mainly along the Cannero stream (N46 1'37"; E8 $\left.{ }^{\circ} 39^{\prime} 24^{\prime \prime}\right)$. This work allows unraveling, for the first time in this area, how different ore parageneses superimpose each other. Two mineralization styles have been detected. The first (Type a) is mainly made by mm-grained arsenopyrite, pyrite and pyrrhotine in quartz-carbonatic gangue, with sometimes important amounts of scheelite and gold. The second (Type $b$ ) is represented by less than mm-grained arsenopyrite, pyrite and galena accompanied by mm-grained scheelite, apatite, and electrum. Despite more data are needed to better constraint the structural framework, temperature, timing and the source of the ore fluids, our preliminary data suggest a new possible pre-Alpine deposit.

KEY WORDS: Western Alps, Southern Alpine Domain, vein, mineralization, gold, scheelite.

\section{INTRODUCTION}

Gold-bearing deposits are the result of a complex combination of geological processes, which cause the local enrichment in the Earth's crust about this mineral of economic interest. In Italy, gold is a precious mineral discreetly widespread (e.g. Funedda et al., 2018), mainly along the Alpine and Apennine chain. In the Western Alps, primary gold deposits (Pettke et al., 1999) are generally associated with a network of veins directly linked to ductilebrittle late tectonic, which cross-cut the already present Alpine compressive structures (Cerri et al., 2017). Most of these are commonly described as orogenic gold deposits (Groves et al., 1998, 2018), synchronous with deformation and metamorphism in collisional frameworks. Despite the genetic connection between mesothermal gold-bearing ores and intrusive rocks have been long recognized, intrusions related gold systems (IRGS; Orlandea \& Vlad, 2020 and references therein) have been called upon to describe the genesis of an increasing number of gold deposits
(Hart, 2005). This include a strong relationship with the structural evolution, but still controversial remain of the "orogenic" gold deposits (Sillitoe \& Thompson, 1998). The Southern Alpine domain, since it has been slightly affected by the Alpine orogenesis (Crespi et al., 1982), is an interesting sector to unravel possible pre-Alpine mineralized systems, strongly affected by Variscan and post-Variscan structural evolution. This study presents new preliminary field observation, petrographical, SEM-EDS and geochemical data regarding the never mined Cannero Riviera mineralized system (VCO province, Italy), which can highlight a pre-Alpine genesis probably. Furthermore, some mafic bodies outcrops along the mineralized belt and play a key role in investigating a possible Reduced Intrusion Related Gold System (RIRGS; Hart, 2005 and references therein).

\section{REGIONAL AND LOCAL SETTING}

In the Western Alps, the Variscan basement is mainly exposed in the Africa-verging Alpine belt (Southern Alpine domain; Dal Piaz and Martin, 1998; Fig. 1a), which has been only slightly affected by Alpine metamorphism and deformation (Crespi et al., 1982; Schumacher 1990). The study area is located in the "Massiccio dei Laghi" (Novarese, 1929), divided into the Ivrea-Verbano Zone and the Serie dei Laghi (Boriani et al., 1977). The boundary between the Serie dei Laghi and Ivrea-Verbano zone is represented by the Cossato-Mergozzo-Brissago Line (CMBL; Boriani \& Sacchi, 1973; Boriani et al., 2016; Fig. 1b), active during Permian age (Mulch et al., 2002), containing mylonitic rocks and mafic and granitic igneous lenses intruded contemporaneously with its movement (Boriani et al., 2016). The investigated area, few kilometres south of the CMBL, is in the Serie dei Laghi Unit consisting of (Fig. 1b): (i) Scisti dei Laghi unit mainly made by amphibolite facies micaschists and paragneisses, locally re-equilibrated under greenschist facies conditions. The most widespread mineral association is quartz, plagioclase, white mica, biotite and syn- to inter-kinematic garnet and staurolite porphyroblasts; (ii) Orthogneisses \& metagranites (466 Ma; Boriani et al., 1982, 1983), defined by the alternation of sub-millimetric levels of biotite, 


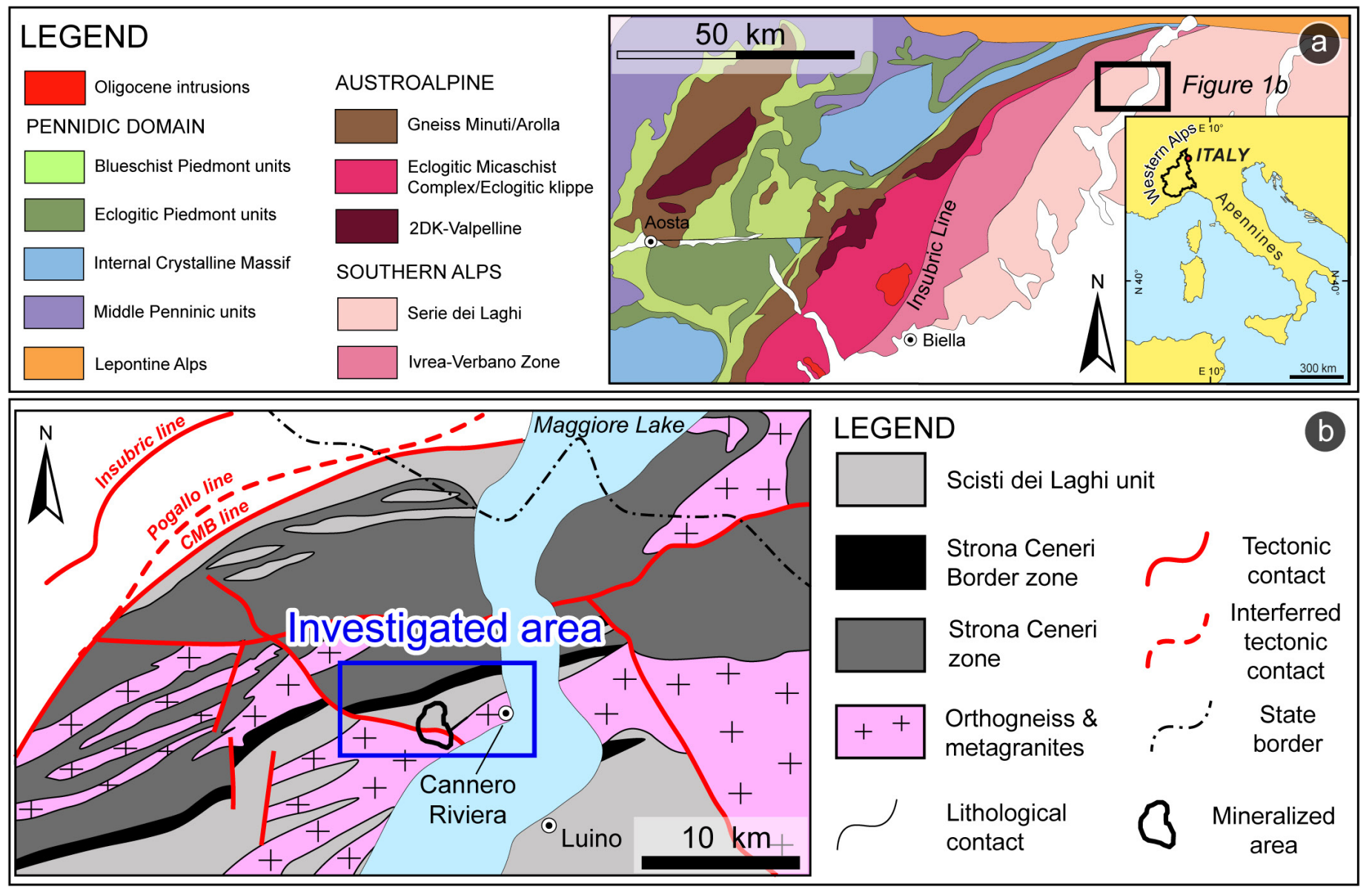

Fig. 1 - (a) Sketch map of the Western Alps (modified from Beltrando et al. (2010)) with its geographic location; (b) Geological sketch of the Cannero Riviera area (modified from Boriani et al., 1990). The orebody shape and position has been indicated.

chlorite and minor hornblende, and pluri-millimetric quartzose-feldspathic levels characterized by medium-fine grain size; (iii) Strona Ceneri Border zone, represented by massive and layered amphibolites with plagioclaserich and green amphibole-rich levels intercalated with quartz and plagioclase bands; (iv) Ceneri Gneiss unit, consisting in biotite-bearing gneiss, with low white mica content, and millimetric garnet and sub-millimetric kyanite porphyroblasts; (v) Gneiss Minuti unit, composed of fine-grained gneiss with quartz, plagioclase, muscovite, biotite, kyanite and minor chlorite. Ceneri Gneiss unit and Gneiss Minuti unit are both included in the Strona Ceneri zone (Bergomi et al., 2008; Fig. 1b). Preliminary field and structural data highlight in the study area a polyphasic deformation history. The main structural element is the Sp foliation, defining the lithological contacts. This is the product of a folding process developing an axial plane foliation, which generally transposes a previous one ( $\mathrm{Sp}$ 1), only locally preserved (D1; Borghi, 1989; Zurbriggen et al., 1997). The Sp foliation, striking about NE-SW with generally high dip angles, is also associated with kinematic indicators increasing toward the Cannero Riviera Fault. The biotite and white mica assemblage, with garnet and staurolite porphyroblasts, confirms the amphibolite facies well known as the D2 deformation stage in the literature (340-330 Ma; Borghi, 1989; Pinarelli \& Boriani, 2007). The Sp foliation is folded by different folds type $(\mathrm{Fp}+1)$, from "schlingen folds" to kink, chevron and/or asymmetric geometry, with rounded hinges and locally asymmetric profiles. The $\mathrm{Dp}+1$ deformation phase increase in intensity moving towards the Cannero Riviera Fault. An axial plane foliation is generally not well developed, but locally a crenulation cleavage $(\mathrm{Sp}+1)$ with the growth of chlorite in the hinges of folds has been observed (D3; Zurbriggen et al., 1997). Based on cross-cutting relations between folds and minor intrusives that have been dated radiometrically along the CMBL, the "schlingen folds" and the greenschist facies condition of the D3 stage is widely believed to have formed during Hercynian igneous and metamorphic activity (300-290 Ma; Zurbriggen et al., 1997). Locally, mafic vertical sheet-like bodies, mostly concordant with the mylonitic foliation and displaying a cataclastic texture, similar to the Cossato-Mergozzo-Brissago Line framework dated at about 295-285 Ma (U-Pb monazite age; Koeppel \& Gruenenfelder, 1978/ 1979; Cumming et al., 1987), occur along the Rio Cannero Fault.

\section{MATERIALS \& METHODS}

Cannero Riviera area was investigated in its preliminary meso-, microstructural, petrographic and metallogenic features employing sampling activity resulting in a batch of about 82 oriented samples, derived 

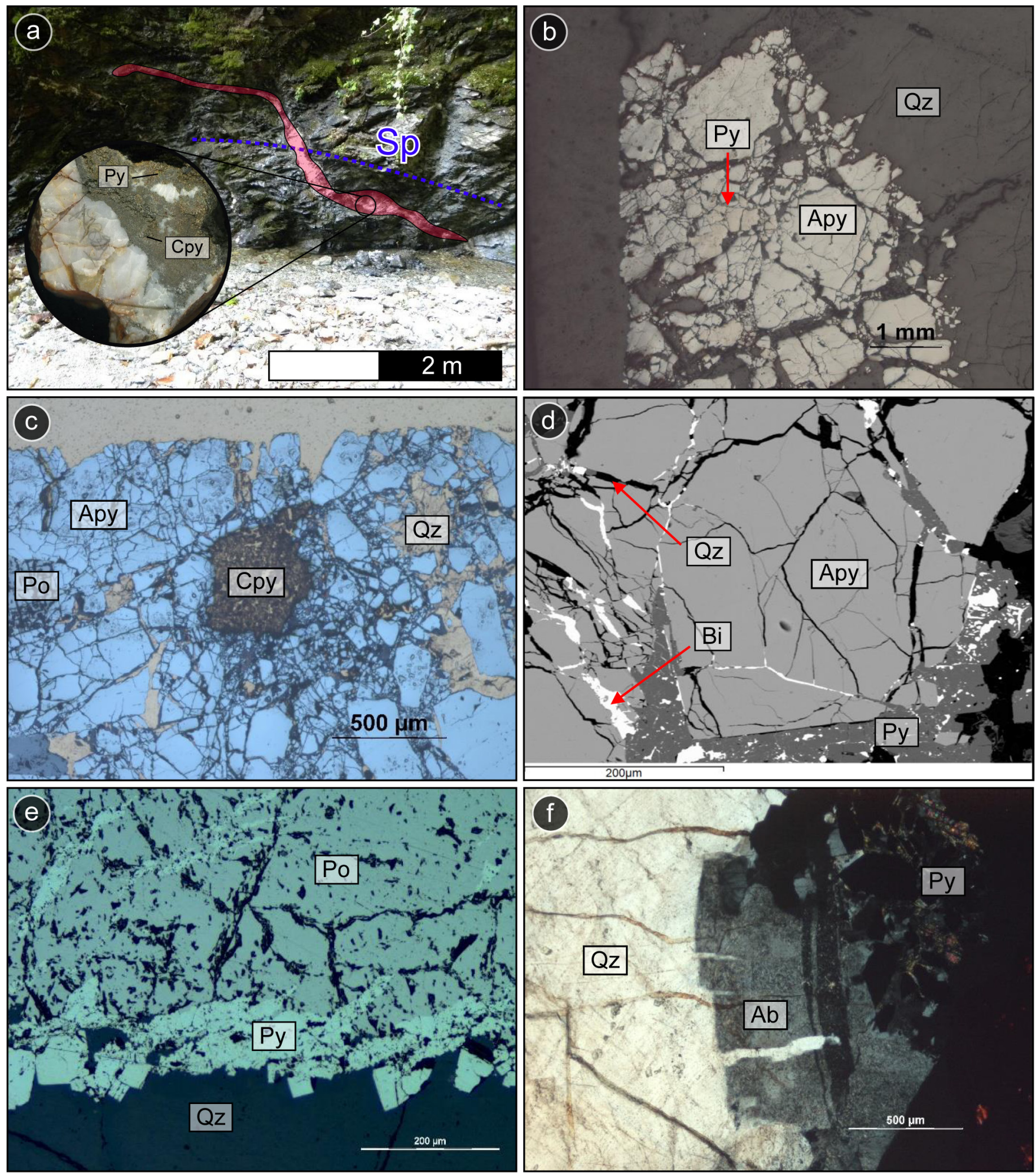

Fig. 2 - (a) Discontinuous vein (Type a) outcrop of about $60 \mathrm{~cm}$ thick, discordant to the regional foliation (Sp); (b) Detail of Type a arsenopyrite, highly fractured, with inclusions of pyrite (reflected light); Detail of intensely cracked chalcopyrite (c) and arsenopyrite (d) in Type $a$ mineralization (reflected+trasmected and BSE respectively); (e) Pyrite preferential position among Type a mineralization sulphides and quartzitic gangue (reflected light); (f) Detail of albite along the contact between Type a mineralization and quartzitic gangue. Both albite and quartz are visibly fractured (XPL). 
from Oberto's Master Thesis (2019) fieldwork. 30 selected samples underwent mineralogical and micro-textural characterization by optical microscopy (transmitted and reflected light). Subsequently, a selection of sulphidesbearing samples was polished and C-coated in order to be inspected using a Scanning Electron Microscope (SEM-EDS; JEOL JSM IT300LV), at the University of Torino (Italy), which allowed us to distinguish the mineralogical phases, performing qualitative chemistry. Quantitative chemical analysis of the samples analyse the gold and tungsten presence and were performed by ICP and XRF techniques conducted by Alpine Gold Lodes Snc (see caption 4). Gold and scheelite have prospected during the alluvial heavy sediments survey downstream the mineralized body. The sediments were panned and the related concentrate was collected. Then, these heavy granules have been glued on a thin section and analysed at SEM-EDS. The abbreviations of the minerals used during the following petrographic description are taken from Whitney \& Evans (2010).

\section{FIELD OBSERVATIONS AND MINERALOGY}

The Cannero Riviera orebody outcrops about 0,5 $\mathrm{Km}^{2}$ at N46 ${ }^{\circ}{ }^{\prime} 37^{\prime \prime} ; \mathrm{E} 8^{\circ} 39^{\prime 2} 24^{\prime \prime}$ and displays roughly a subcircular shape (Fig. 1a). It is hosted in the most complex structural framework of the investigated area, where the mylonitic Ordovician orthogneiss and Variscan micaschists/ paragneisses belonging to Scisti dei Laghi unit exhibit brecciated textures due to the Rio Cannero Fault activity. Ore minerals occur as a stockwork of discontinuous discordant and concordant veins (Fig. 2a), displaying numerous sulphides-rich oreshoots, in which arsenopyrite is the most recurrent mineral, alternating with poorly mineralized zones, in a quartz-carbonatic gangue. Furthermore, the geochemical analyses performed on mineralized samples and carried out by the current mining company (Alpine Gold Lodes Snc), operating in the Cannero Riviera mining exploration survey (from 2016 up to now), highlighted the presence of gold and scheelite related to the sulphides-rich oreshoots. Two distinct kinds of ores (Type $a$ \& Type $b$ ), based
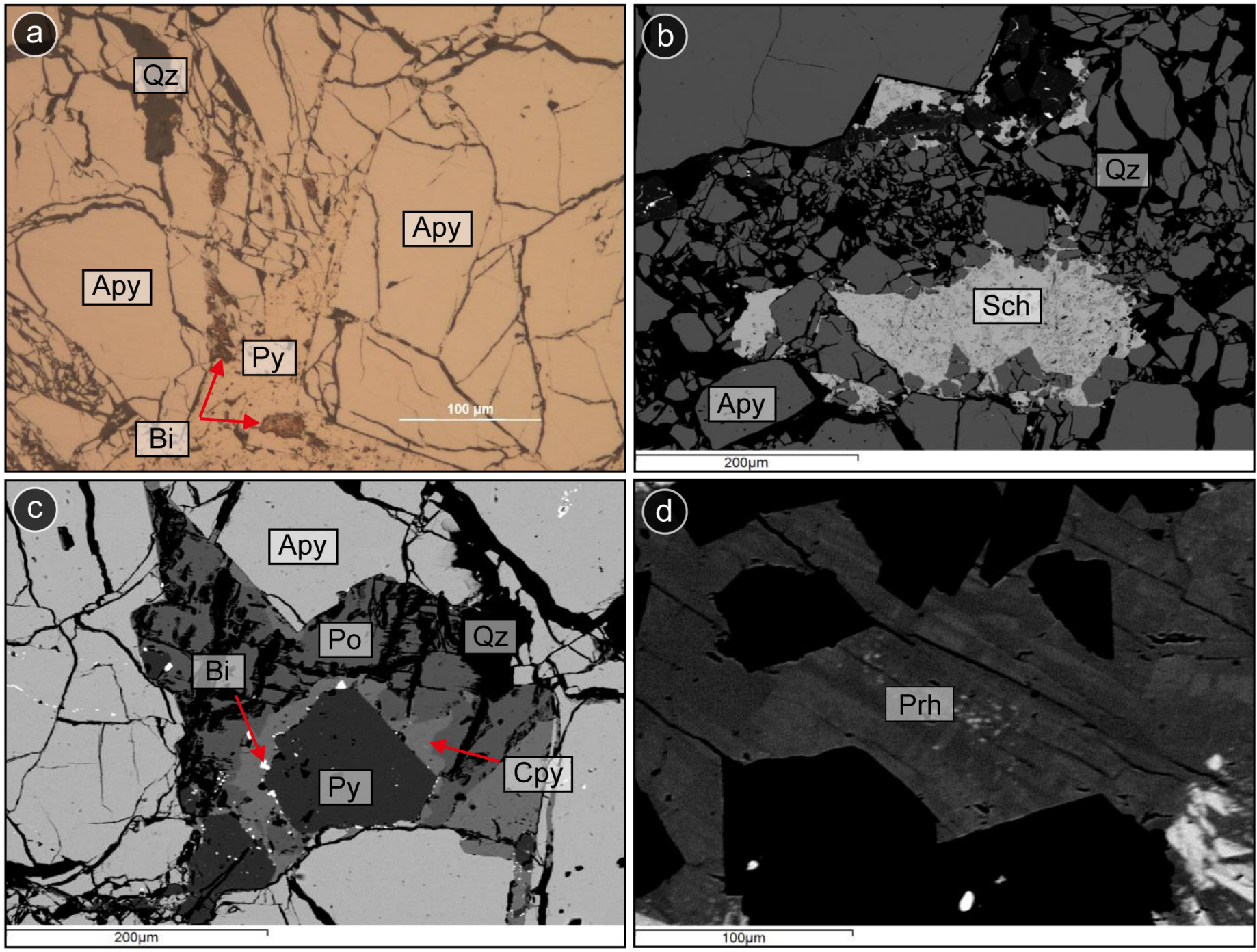

Fig. 3 - (a) Exemple of overprinting relationship of Type $b$ veins with native bismuth and pyrite that cross-cut arsenopyrite crystals, filling the open spaces (reflected light); (b) BSE focus of scheelite filling in Type $b$ veins, cementing the arsenopyrite fractures (Type a); (c) Type $a$ mineralized portion with pyrite and arsenopyrite, intensely fractured. Around pyrite, discontinuous chalcopyrite and native bismuth rims are present, while quartz and pyrrhotine fill the remaining portions (BSE); (d) Undeformed prehnite in Type $b$ veins (BSE) 
on the different mineral assemblage, spatial relationships and overprinting criteria, have been detected.

\section{TYPE A}

This is the most recurrent system and it is made by a network of veins typically about $50 \mathrm{~cm}$ thick, few metres long, often parallel to the regional foliation (Sp) and just rarely discordant (Fig. 2a). Veins are often intensely folded by isoclinal structures "schlingen folds" and show a cataclastic texture. The matrix is mainly made by quartz and carbonate. In order of abundance, the Type a system is composed by euhedral arsenopyrite (Fig. 2b), pyrite and medium-grained pyrrhotine, chalcopyrite (Fig. 2c), blende, scheelite and gold/electrum. Disseminated fluorite, albite and titanite (less than $0.5 \mathrm{~mm}$ in diameter) are also present. In some sectors, the arsenopyrite shows microinclusions of pyrite (Fig. 2d), pyrrhotine, chalcopyrite and quartz (0.2 $\mathrm{mm}$ in diameter). The grain-size of the mineral assemblage is strongly linked to the brittle deformation (Fig. 2d) increasing going towards the Rio Cannero Fault. Gangue minerals are quartz (Fig. 2e) and minor carbonate, followed by less carbonate. Quartz often displays an undulose extinction and is strongly fractured. Locally discontinuous pyrite rim between sulphides and quartzitic gangue has been detected (Fig. 2e). A mm-thick alteration rim characterized by chlorite, epidote and albite (Fig. 2f) at the edges of the sulphides-rich veins is also present. Radiate chlorite has been observed.

TYPE B

The second vein-type consists of elongated and mmup to cm-thick micro-veins (just a few centimetres long),

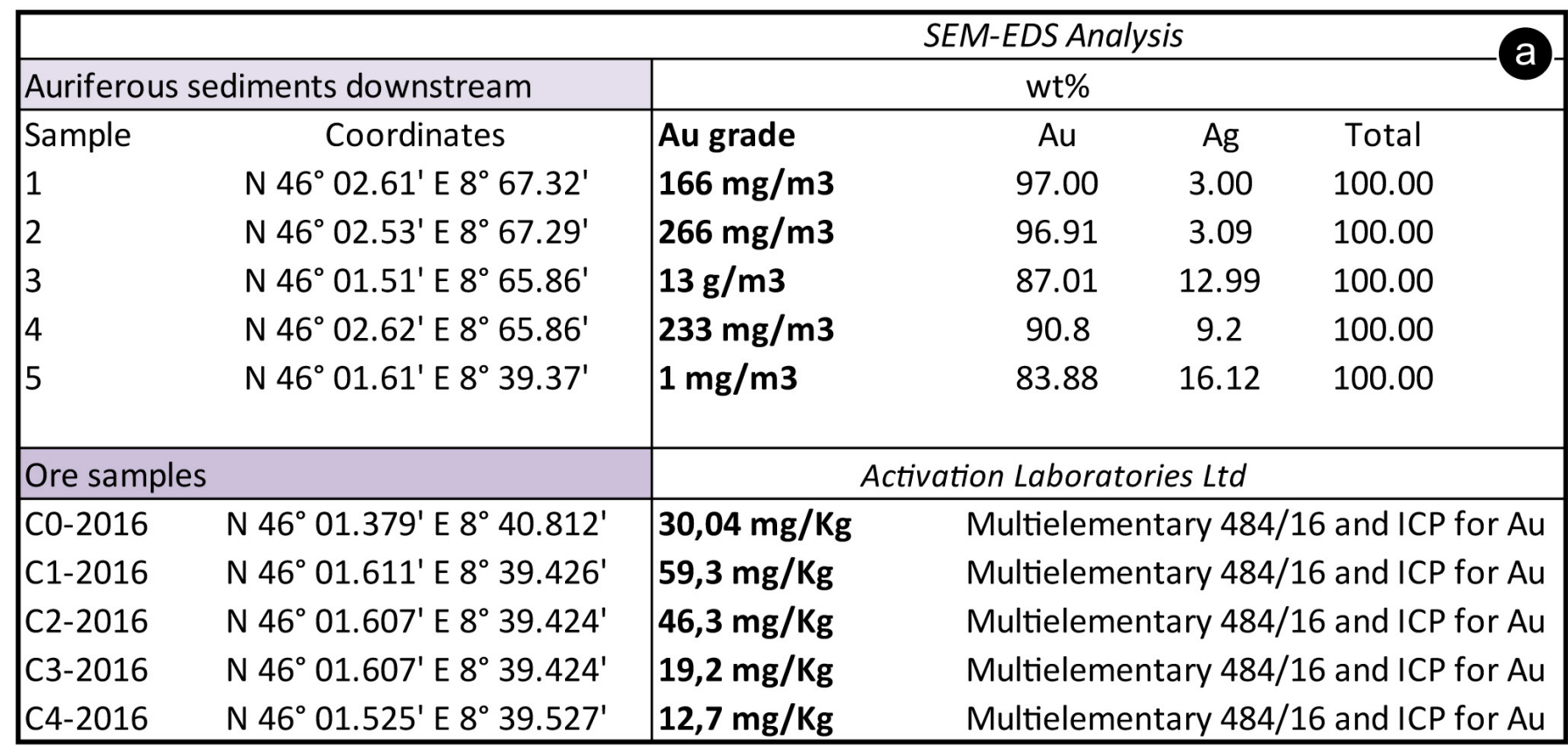
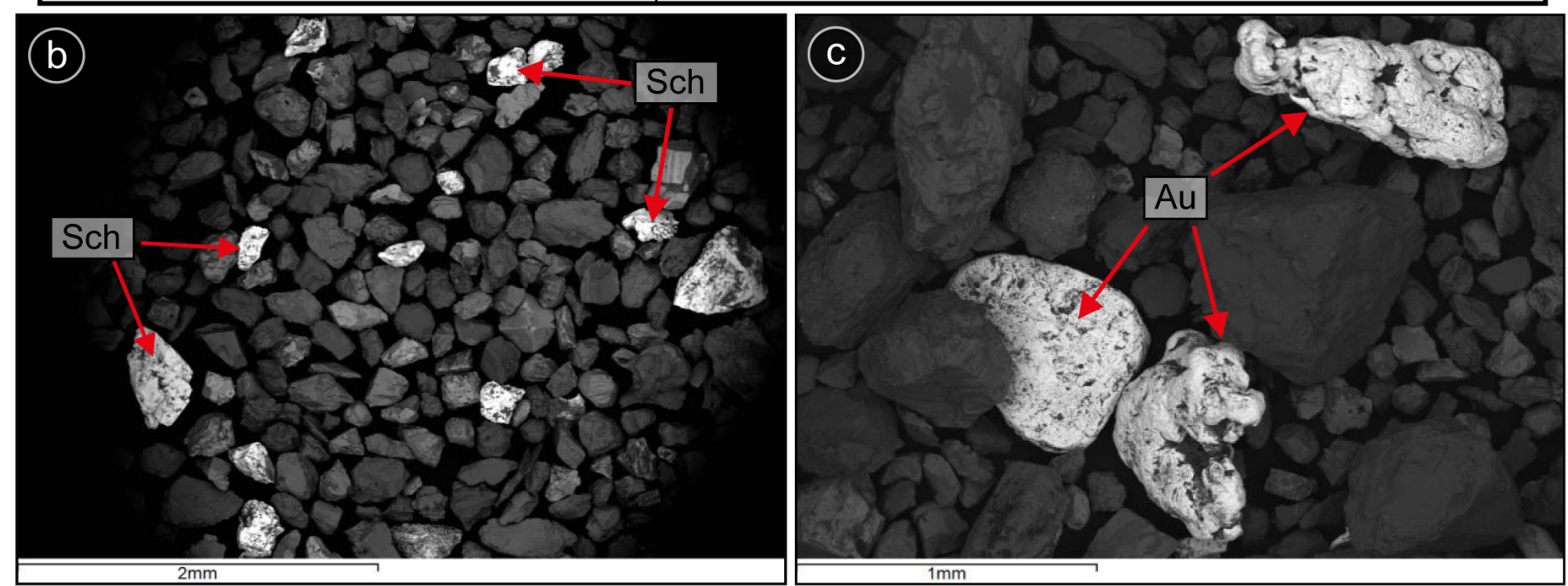

Fig. 4 - (a) Summary table of the data obtained from the alluvial heavy sediment survey. Microphotography at SEM-EDS of scheelite granules (b) and gold flakes (c). 
which cuts, overprints and brecciates the Type $a$ (Fig. 2b,c,d) veins and host rocks. This mineralization is a randomly distributed stockwork (Fig. 3a) of medium-fine grained arsenopyrite (up to $0.5 \mathrm{~mm}$ in diameter), pyrite, pyrrhotine, chalcopyrite and scheelite (Fig. 3b), with minor native bismuth, bismuthinite, bismuth sulphosal and tellurium (all are less than $0.3 \mathrm{~mm}$ in diameter) in carbonate-quartz gangue. Locally, chalcopyrite rims around pyrite (Fig. 3c) and along cataclastic horizons are present. Sometimes, Type $b$ assemblage forms a discontinuous rim around Type a mineral, mainly made by bismuth and pyrrhotine (Fig. 3c). Native bismuth is one of the most abundant phases and is generally located in not-deformed veins (Fig. 3a). Locally, quartz and slightly Fe-rich carbonate (FeOtot $<2.0$ wt.\%) not-mineralized veins have been detected. Furthermore, undeformed low Fe-rich prehnite (FeOtot < 3.19 wt.\%; Fig. 3d) has been found in micro-veins with a diameter of $0.2 \mathrm{~mm}$ as average. At the edges of these veins, a $0.2 \mathrm{~mm}$ thick rim made by sericite, quartz, titanite and pyrite is present.

The heavy-sediment sampling survey has been conducted in the first 3 kilometres downstream of the Cannero Riviera ore. The first hypothesis was that the ore had dispersed gold and scheelite granules over time, thanks to the mechanical erosion and chemical alteration, into Rio Cannero alluvial sediments. 100 sampling stations have been carried out, but just a few of them brought to good results in terms of concentration (Fig. 4a). Scheelite (Fig. 4b), gold (Fig. 4c), magnetite and garnet were detected during the survey. SEM-EDS analysis on gold granules allows highlighting the Au-Ag alloy composition (electrum; Fig. 4a). Moreover, the data acquired during the alluvial heavy sediments sampled downstream the ore confirm the presence of scheelite and its dispersion with gold from the ore explored.

\section{DISCUSSION AND CONCLUSION}

Our preliminary study of the geometry and composition of the mineralized veins, combined with mineralogical and textural analysis, highlights two different kinds of mineralized veins (Type $a$ \& Type $b$ ). Type $a$, generally concordant with the mylonitic foliation along the Rio Cannero Fault (Fig. 5), displays a cataclastic texture and an increase of brittle deformation going towards the damage zone (Fig. 5). Type $a$ is cut by a micro-veins filled stockwork (Type $b$ ). The brittle overprinting on the mylonitic structures highlights the strong relationship between the ore body evolution and the ductile-brittle activity transition of the Rio Cannero Fault. The association of chlorite, albite and epidote with Type a mineralization is a typical paragenesis of hydrothermal alteration, belonging to the propylitic facies (Evans, 1993). The lack of the preferential orientation of the new-growing minerals confirms the hydrothermal alteration origin. The absence of amphibole and biotite suggests that it should be linked to the circulation of fluids with a roughly neutral pH in relatively deep mesothermal conditions (Corbett \& Leach, 1998; Robb, 2005; Fig. 5). The following mineral association (sericite, quartz and pyrite) related to the Type $b$ mineralization, corresponds to a classic hydrothermal phyllic facies alteration (Corbett \& Leach, 1998; Evans, 1993; Fig. 5). The two hydrothermal alterations highlight a
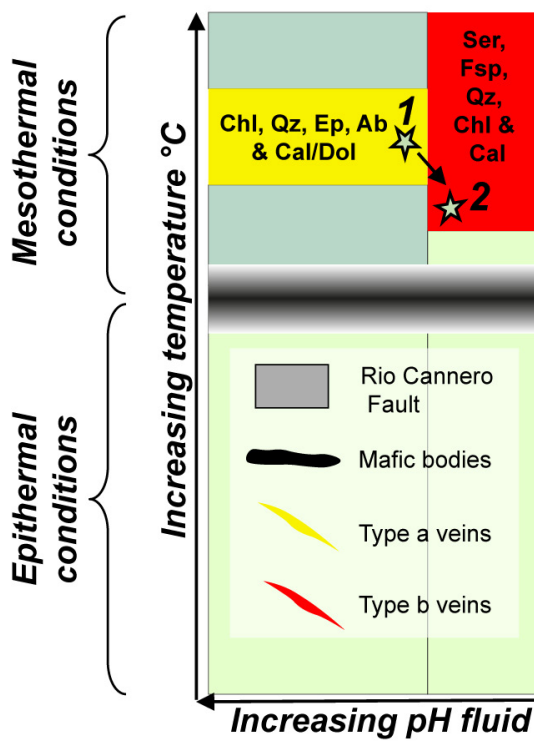

Rio Cannero Fault ductile activity (Type a)

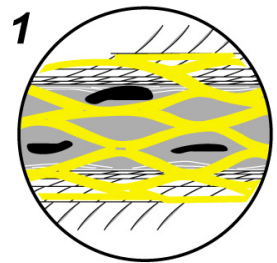

Rio Cannero Fault brittle activity (Type b)

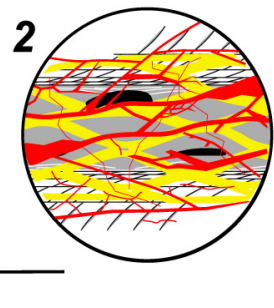

Fig. 5 - Schematic illustration of possible structural evolution of the Type $a$ and Type $b$ vein systems during ductile (1) and brittle (2) Rio Cannero Fault activity. The $\mathrm{pH}$ vs temperature conditions chart (modified from Corbett \& Leach, 1998), considering the different mineral associations, indicates a variation of temperature and $\mathrm{pH}$ remaining in mesothermal conditions.

slight decrease over time in the $\mathrm{pH}$ of the circulating fluids, which reaches a lower $\mathrm{pH}$ 5-6 threshold from $\mathrm{pH}$ 6-7 values (Robb, 2005; Fig. 5). Therefore, the temperature associated with the circulating fluids can vary from 200 up to $500^{\circ} \mathrm{C}$, even if the fine-grained sericite suggests a medium-low temperature $\left(200-300^{\circ} \mathrm{C}\right)$. As for the gangue, it should be noted that carbonate increases in abundance between the two considered mineralization styles. This should underline a different composition in Type $b$ hydrothermal fluids (Robb, 2005). Also, the presence of fluorite, scheelite, bismuth and tellurium phases as well as the absence of carbonation phenomena related to Type a mineralization vein system, could be related to a magmatic origin of the hydrothermal mineralizing fluids (Sillitoe, 1991). According to Borghi, 1989, the prehnite, in Southern Alpine domain, is a typical Alpine-related mineral. The presence in Type $b$ veins of undeformed prehnite could indicate Alpine Orogenesis timing. Therefore, the Cannero Riviera ore shows notable differences from other well-studied gold ore deposits (e.g. Monte Rosa Gold District; Curti, 1987). The association of fluorite, scheelite and bismuth, and the absence of carbonation phenomena indicate a probable magmatic related Au origin (e.g. Tintina gold belt; Hart and Goldfarb, 2005). The presence of brittle deformed mafic bodies emplaced along the Rio Cannero Fault (Fig. 5) and mainly concordant with the mylonitic foliation, similar to the Cossato-Mergozzo-Brissago Line framework (about $295 \mathrm{Ma}$ U-Pb monazite age; Koeppel \& Gruenenfelder, 1978/ 1979; Cumming et al., 1987), indicates a possible relationship with the Reduced Intrusion Related Gold System (RIRGS; Hart, 2005). The presence of mafic bodies and the cross-cut relationship gives a pre-Alpine orogenesis timing to the Type a system. However, more studies should be made to deep investigate the real genesis of the mafic bodies along the Rio Cannero Fault, which could be related 
to mafic intrusions or lenses of the Strona-Ceneri border zone. It is still not clear the importance of the Rio Cannero activity and the real number of reactivations related to several remobilizations showed by the mineralization itself. However, more data are needed to better constraint the structural framework, temperature, timing and the source of ore fluids. In conclusion, our results provide a new preliminary data to highlight the possible presence of gold-bearing primary pre-Alpine deposits in the Cannero Riviera area in the Western Alps.

\section{ACKNOWLEDGEMENTS}

We thank the following colleagues and institutions for their contributions and support: Dr Savaris Paolo (Geologist chief director of Alpine Gold Lodes S.n.c.), Vicario Piergiorgio and Vicario Alessandro (Project owners of Alpine Gold Lodes), Department of Earth Sciences of the University of Turin and colleagues involved in the SEM-EDS laboratory. This article has been redacted as a memory of Piergiorgio Rossetti, who passed away during August 2019. As his students, we remember him as our master and guide.

\section{REFERENCES}

Beltrando M., Compagnoni R. \& Lombardo B. (2010) - (Ultra-) highpressure metamorphism and orogenesis: An Alpine perspective. Gondwana Res., 18, 147-166.

Bergomi M., Boriani A., Caironi V. \& Pinarelli L. (2008) - The protolith of the cenerigneiss (Serie dei Laghi - NW Italy) and its paleogeographic significance. Rend. On. Soc. Geol. It., 2, 1-3.

Boriani A. \& Sacchi R. (1973) - Geology of the junction between the Ivrea-Verbano and Strona-Ceneri Zones (Southern Alps). Mem. Ist. Geol. Min. Un. Padova, 28, 1-36.

Boriani A., Bigioggero B. \& Giobbi Mancini E. (1977) - Metamorphism, tectonic evolution \& tentative stratigraphy of the "Serie dei Laghi": Geological map of the Verbania area (Nothern Italy). Mem. Soc. Ital., 32, 1-26.

Boriani A., Caironi V. \& Sacchi R. (2016) - The CMB Line: the southern margin of the Ivrea-Verbano Zone (basement of Southern Alps, Italy): a re-appraisal. Rend. Fis. Acc. Lincei, 27, 673-678.

Boriani A., Giobbi Origoni E. \& Del Moro A. (1982-1983)-Composition, level of intrusion and age of the "Serie dei Laghi" orthogneisses (Northern Italy - Ticino, Switzerland). Rend. Soc. Ital. Mineral. Petrol., 38, 191-205.

Boriani A., Giobbi Origoni E., Borghi A. \& Caironi V. (1990) Evolution of the "Serie dei Laghi" (Strona-Ceneri \& Scisti dei Laghi): the upper component of Ivrea-Verbano crustal section: Southern Alps. Tectonophysics, 182, 103-118.

Borghi A. (1989) - L'evoluzione metamorfico-strutturale del settore nord-orientale della Serie dei Laghi. Unpublished Ph.D thesis, University of Turin, $187 \mathrm{pp}$.

Cerri R., Bettoni I. \& Nanni V. (2017) - Il distretto aurifero del Monte Rosa: lo sfruttamento minerario di ieri per quello turisticoculturale di domani. Convegno "L'attività mineraria nelle Alpi, il futuro di una storia millenaria"; XXVI edizione, 1-81.

Corbett G.J., \& Leach T.M. (1998) - Southwest Pacific gold-copper systems: Structure, alteration and mineralization. Soc. Econ. Geol., 6, 238-240.

Crespi R., Liborio G. \& Mottana A. (1982) - On a widespread occurrence of stilpnomelane to the South of the Insubric line, Central Alps, Italy. Neues Jb. Miner. Monat., 6, 265-271.
Cumming G.L., Koeppel V. \& Ferrario A. (1987) - A lead isotope study of the northèastern Ivrea Zone and the ad. joining Ceneri zone (N-Italy): evidence for a contaminated subcontinental mantle. Contrib. Mineral. Petrol., 97, 19-30.

Curti E. (1987) - Lead and oxygen isotope evidence for the origin of the Monte Rosa gold lode deposits (western Alps, Italy): a comparison with Archean lode deposits. Econ. Geol., 82, 2115-2140.

Dal Piaz G. \& Martin S. (1998) - Evoluzione litosferica e magmatismo nel dominio austro-sudalpino dall'Orogenesi Varisica al rifting mesozoico. Mem. Soc. It., 53, 43-62.

Orlandea E. \& Vlad S.N. (2020) - A novel conceptual model of intrusion-related gold bearing systems and exploration tools. Stud. U. Babes-Bol. Geol., 63 (1), 1-2.

Evans M.A. (1993) - Ore geology and industrial minerals. Blackwell Publishing, 1-430.

Funedda A., Naitza S., Buttau C., Cocco F. \& Dini A. (2018) - Structural Controls of Ore Mineralization in a Polydeformed Basement: Field Examples from the Variscan Baccu Locci Shear Zone (SE Sardinia, Italy). Minerals, 456.

Groves D.I., Goldfarb R.J., Gebre-Mariam M., Hagemann S.G. \& Robert F. (1998) - Orogenic gold deposits: A proposed classification in the context of their crustal distribution and relationship to other gold deposit types. Ore Geol. Rev., 13, 7-27.

Groves D.I., Santosh M., Goldfarb R. \& Zhang L. (2018) - Structural geometry of orogenic gold-deposits: Implications for exploration of world-class and giant deposits. Geosci. Front., 9-13.

Hart C.R.J. (2005) - Classifying, distinguishing and exploring for intrusion-related gold systems. The Gangue, Geological Association of Canada, Mineral Deposits Division, 87, 4-9.

Koeppel V. \& Gruenenfelder M. (1978, 1979) - Monazite and zircon $\mathrm{U}-\mathrm{Pb}$ from the Ivrea and Ceneri Zones (Ivrea-Verbano). Mem. Sci. Geol., 33, 1-257.

Mulch A., Rosenau M., Dorr W. \& Handy M.R. (2002) - The age and structure of dikes along the tectonic contact of the IvreaVerbano and Strona-Ceneri Zones (southern Alps, Northern Italy, Switzerland). Schweiz. Mineral. Petrogr., 82, 55-76.

Novarese V. (1929) - La Zona del Canavese e le formazioni adiacenti. Memorie Descrittive Della Carta Geologia d'Italia, 22, 65-212.

Oberto M. (2019) - Studio geologico strutturale, petrografico e metallogenico delle mineralizzazioni aurifere presso Cannero Riviera (VCO). Unpublished Master thesis, University of Turin, 201 pp.

Petke T., Diamond W.L. \& Villa M.I. (1999) - Mesothermal gold veins and metamorphic devolatilization in the northwestern Alps: the temporal link. Geology, 27, 641-644.

Pinarelli L. \& Boriani A. (2007) - Tracing metamorphism, magmatism and tectonics in the southern Alps (Italy): constraints from Rb$\mathrm{Sr}$ and $\mathrm{Pb}-\mathrm{Pb}$ geochronology, and isotope geochemistry. Mineral., $76,5-24$.

Robb L. (2005) - Introduction to ore-forming processes. Blackwell Publishing, 1-430.

Schumacher M.E. (1990) - Alpine basement thrusts in the eastern Seenbirge, Southern Alps (Italy/Switzerland). Eclogae Geol. Helv., 83, 645-663.

Sillitoe R.H. (1991) - Intrusion-related gold deposits. Gold Metallogeny and Exploration, 1, 165-209.

Sillitoe R.H. \& Thompson J.F.H. (1998) - Intrusion related vein gold deposits: Types, tectono magmatic setting and difficulties of distinction from orogenic gold deposits. Res. Geol., 48, 237-250.

Whitney D.L. \& Evans B.W. (2010) - Abbreviations for names of rock forming minerals. Am. Mineral, 95, 185-187.

Zurbriggen R., Franz L. \& Handy M.R. (1997) - Pre-Variscan deformation, metamorphism and magmatism in the StronaCeneri Zone (southern Alps of northern Italy and southern Switzerland). Schweiz. Mineral. Petrogr., 77, 361-380. 